\title{
THE INFLUENCE OF BRAND EXPERIENCE AND EMOTIONAL ATTACHMENT ON BRAND TRUST AND BRAND LOYALTY CHURCH MAWAR SHARON, WEST SURABAYA
}

\author{
Hans Christian Harjanto \\ Lena Ellitan \\ Ninuk Muljani \\ Widya Mandala Surabaya Catholic University \\ hanschristianharjanto@gmail.com \\ lena@ukwms.ac.id \\ ninuk@ukms.ac.id
}

A R T I C L E I N F O

\author{
Article history: \\ Received: 5 March 2021 \\ Revised: 9 April 2021 \\ Accepted: 9 April 2021
}

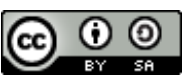

Keywords:

Brand Experience; Emotional Attachmen; Brand Trust; Brand Loyalty

DOI:

https://doi.org/10.33508/rima.v4i1.3062

\begin{abstract}
A B S T R A C T
This study aims to analyze the effect of brand experience and emotional attachment on brand trust and brand loyalty in Mawar Sharon Church in West Surabaya. Currently, the level of membership, attendance, and participation in Christian churches has decreased. The data analysis technique used is SEMPLS analysis with the SmartPLS program. The research results prove that brand experience has a significant effect on emotional attachment and brand loyalty, but insignificant on brand trust. Emotional attachment has a significant effect on brand trust and brand loyalty. Brand trust has a significant influence on brand loyalty. The role of emotional attachment is also significant as a mediator for brand experience on brand trust and brand loyalty. The role of brand trust as a mediator for brand experience and brand loyalty is insignificant. Suggestions from research for the Mawar Sharon Church in West Surabaya are to take a personal approach to the congregation and create programs, so that there is a personal bond between the congregation and the Mawar Sharon Church in West Surabaya and increase the congregation's trust and attachment to the church. but insignificant on brand trust.
\end{abstract}

\section{INTRODUCTION}

From the perspective of Christianity, membership, attendance, and participation in religious institutions have decreased(Granger, Lu, Conduit, Veale, and Abel, 2014). This decline is due to a lack of interest in the younger generation; increased opportunities to spend leisure time in other ways compatible with economic growth; perceptions of moral and ethical failures in faith-based organizations; disappointment with the value given (Granger et al., 2014); trends in church migration and migration(Schoeman, 2014); increased secularization; the less openness it is to the idea of the church, the church is no longer mainstream; or changing perceptions about church involvement(Barna Group, 2014).

Recent research has also found that relationships are a key aspect of younger generations staying with a church or leaving. Positive relationships (including leadership) motivate young people to become involved with the church. On the other hand, negative relationships motivate younger generations to break away(Mullen, 2020).

Over the last decade, academics and marketers have shifted the focus from a functional meaning to a brand-related consumer experience meaning (Schmitt and Rogers, 2008: 10; Khan and Rahman, 2017). It also has to do with marketing within the church sphere. One of the main reasons for explaining the reason people leave the church is an unfulfilled desire. In other words, the congregation has a desire for what the local church should provide and will leave if that wish has not been fulfilled (Rainer, 2013).

Belk(1988) argues that emotional attachments will not exist if customers do not have an intense experience of consuming a brand. Brakus, Schmitt, and Zarantonello (2009) argue that consumers who have experience with a brand while looking for the right product, making purchases, and using it are known as brand experience. If they have 
a positive experience, consumers are predicted to be happy to repurchase the brand. In this case, the consumer is the congregation of the church concerned.

Booysen(2016) found that brand experience acts as a mediator of loyalty and satisfaction of church congregations observed in Christianity. The study determined that brand experience occurs in the religious market and that it is influenced by the five dimensions of brand experience, namely intellectual, behavioral, sensory, relational, and emotional. Thus, a high brand experience can attract new congregations, reduce church-moving behavior, and reduce the possibility of congregants leaving.

However Booysen (2016) has not tested the effect of emotional attachment on congregational loyalty. Numbers Research Center(2018: 45) revealed that "for the younger generation, especially adolescents, the aspect of koinonia (fellowship, community, true friendship, camaraderie) is an essential foundation or venue that is very conducive to faith growth, for the depth of participation (engagement) in the life and ministry of the church."

Research Khan and Rahman (2017)shows that brand experience positively affects emotional attachment. Brand experience and emotional attachment have a significant positive effect on brand loyalty. The results also show that gender moderates the relationship between emotional attachment and brand experience with brand loyalty. Research resultArdyan, Kurnianingsih, Rahmawan, Wibisono, and Winata (2016)found that brand experience affects brand trust and emotional attachments. Emotional attachment also affects brand trust positively and significantly, but brand trust has a positive but insignificant effect on brand loyalty.

To manage a group of people, management knowledge is needed. Church management, especially in marketing has been researched before by many marketing researchers. Many churches have applied marketing strategies, especially large or megachurch churches. Megachurch generally refers to Protestant Christian congregations with an average weekly attendance of 2,000 people or more in their worship services, counting all adults and children in all worship locations (Thumma and Travis, 2007: 2). Mawar Sharon Church (GMS) has succeeded in becoming one of the megachurches in Surabaya.

The following is the data on the number of congregations who worshiped for 5 years.

Table 1: Attendance of Worship

\begin{tabular}{|l|l|l|}
\hline Year & $\begin{array}{c}\text { Number of At- } \\
\text { tendance for 4 } \\
\text { Times of Worship } \\
\text { Hours (person) }\end{array}$ & $\begin{array}{c}\text { Average Attend- } \\
\text { ance for Every } \\
\text { Time of Service } \\
\text { (person) }\end{array}$ \\
\hline 2011 & 5855 & 1464 \\
\hline 2012 & 6200 & 1550 \\
\hline 2013 & 6720 & 1680 \\
\hline 2014 & 7400 & 1850 \\
\hline 2015 & 8200 & 2050 \\
\hline
\end{tabular}

Source: Sunarno and Kristanto, 2016

Although the growth of participation and attendance of Christian church congregations as a whole has decreased, the Mawar Sharon Church (GMS) continues to experience growth. One of the programs that has been successfully implemented is the Connect Group (CG). CG is a community at Mawar Sharon Church, where the congregation is brought together with a spiritual family to be discipled to become more and more like Christ.

This study aims to determine the factors that cause congregational trust and loyalty so that the church congregation continues to grow. This study proposes that brand experience and emotional attachments are strategies that church marketers can use to increase brand trust and brand loyalty.

\section{LITERATURE REVIEW AND HYPOTHESIS DEVELOPMENT}

\section{Brand Experience}

Brand experience is conceptualized as a factor, consisting of a sensory dimension, involving, for example, visual and tactile stimulation; the affective dimension, refers to the feelings the brand generates and the emotional bond with the customer; intellectual dimension, concerning the extent to which the brand can engage customers in analytical and imaginative thinking; and the behavioral dimension, which involves behavioral experiences and motor actions(Coelho, Bairrada, and Coelho, 2020).

According toBrakus et al., (2009), because people seek stimulation and sensory and intellectual pleasure, brand experience emerges as a characteristic or quality brand that is relevant to managing. 
Several other research concerns have been done on brand experience. However, the development of brand experience has had little influence on academic debate(Andreini, Pedeliento, Zarantonello, and Solerio, 2018). According to Khan, Mohammad, and Muhammad (2020), brand experience can affect the impact of measuring brand experience on customer satisfaction, trust, loyalty, word of mouth (WOM), purchase intention, brand loyalty, and brand equity.

Brand experience has been applied in the church. According to Hicks' writing(2012)Hillsong, an Australian megachurch, is the strongest Australian brand. Hicks(2012)analyzed the keys to Hillsong's success, namely Hillsong United's music brand, customer acquisition, message and language, service (brand experience), and brand story. According to Riches and Wagner (2017) Hillsong can be very strong because brand experience and experience of God are closely related so that the congregation becomes co-productive, strengthens themselves, and ultimately, cannot be separated from its political economy context.

City Harvest Church, a megachurch based in Singapore, offers a wider choice of ministries such as audio, bookstores, cheerleading, dance and drama, make-up, photography, business (small / medium enterprises and entrepreneurs), security, and visual communication. These choices enrich the church attendance experience and foster loyalty to the church brand(Yip and Ainsworth, 2013). In this study, the definition of brand experience is a unique experience that is generated through sensory, affective, intellectual, behavioral, and motor skills that are not forgotten and experienced by customers when enjoying the products or services offered at a brand when interacting or every time after interacting with the brand. the. This definition refers to Brakus et al. (2009), Yip and Ainsworth (2013), Riches and Wagner (2017), and Coelho et al. (2020).

\section{Emotional Attachment}

Thompson, MacInnis, and Park, (2005)defines attachment as an emotional bond between a person and a particular object. Emotional attachment reflects the individual's relationship with the consuming entity (brands, people, places, or things) (Park and Macinnis, 2006).Jiménez and Voss (2014)explaining emotional attachments is a relationship-based construct that connects individuals with an object. Park, MacInnis,
Priester, Eisingerich and Lacobucci(2010) argues that brand attachment is the strength of the bonds that connect brands with individuals.

Organizational commitment (whether for a profit or non-profit organization, such as a church) has been defined as a "sense of belonging and loyalty" to the organization. (Cohen, 2013: 526). In this connection,Dunaetz, Cullum, and Barron (2018)defines church commitment as "a Christian congregation's sense of attachment and loyalty to the church it most frequently attends." Several factors that lead to organizational commitment include shared values between congregations in leadership, satisfaction with the work done, and the quality of the relationships one has with other organization members. Some of the consequences of organizational commitment are a willingness to make sacrifices for the organization's welfare, better performance, and lower absenteeism levels (Cohen, 2013: 527).

\section{$\underline{\text { Brand Trust }}$}

Brand trust is conceptually defined as consumers' willingness to rely on the brand's ability to perform the desired function (Chaudhuri and Holbrook, 2001). Research on trust shows difficulty in defining because of its complexity and latent nature(Hobbs and Goddard, 2015). Brand trust research is adapted for marketing and branding(Dowell, Heffernan, and Morrison., 2013). Brand trust is a social phenomenon that occurs in complex and varied relationships between people.Lee, Park, and Cho (2011)believe that consumer trust in a brand means trust in the functioning of its products and services, and further, consumer trust is the trust that a customer has in a brand's ability to continue to provide its true function.

Brand trust is an important element of the relationship between consumers and businesses because customers tend to use trusted brands better (Xie and Peng, 2011). Out of sight Dalziel, Harris, and Laing (2011) brand trust is assessed from the perspective of the reason for reliance on the brand as the capacity and intention to fulfill its promises to consumers. According to Naggar and Bendary (2017), brand trust is seen as perceptions and expectations based on the belief that a brand has certain features and consistent, competent, and credible traits. Similarly, trust has been classified as the primary mediator for long-term relationships that lead to brand loyalty (Naggar and Bendary, 2017). 
In sociology, trusts have been organized into broad categories; namely, institutional trust (trust in a regulatory body), generalized trust (trust in other people), calculative trust (trust based on rational evaluation), and relational trust (trust obtained from time to time and through interaction)(Hobbs and Goddard, 2015). Therefore, in the context of the church, it is more closely related to relational trust.

\section{Brand Loyalty}

Based on Oliver(1999), loyalty is a firmly held commitment to repurchasing a preferred product or service consistently in the future, thus leading to the purchase of the same brands, despite situational and marketing influences that could lead to a shift in behavior. Customer loyalty to a brand represents their long-term commitment to the brand(Reichheld and Teal, 1996: 4). Eskafi, Hosseini, and Yazd (2013) argue that loyalty is obtained when customers believe in the brand's role in promoting its self-image. Therefore, brand loyalty comes by performing services that are deemed to exceed expected expectations. According to Zeithaml, Berry, and Parasuraman(1996), loyal customers spread positive word of mouth, participate in repeat purchases, and are prepared to pay higher prices to buy the brand of choice. Small changes in the customer retention rate can produce a bigger impact on a company's revenue. As a result, increasing brand loyalty has been seen as a key strategy for service providers that emphasizes the company's sustainability and profitability (Morrison and Crane, 2007).

In the context of non-profit organizations (especially churches),Hirschman (1970: 80) in his book stated that loyalty is identified as an element that can influence the cost-benefit analysis of whether someone will protest or leave. The stronger the loyalty to an organization (or to a religion, country, product), the weaker the solution, especially if the alternative is uncertain. Also, it is easier for loyal members to consider putting time and attention into planning how the organization can succeed, once a complaint has been addressed. Wellman and Corcoran(2013)emphasized that the more individuals are confined to their religious group, the greater their level of commitment.

In other words, the more connected and loyal a person is to a religious organization, the greater the level of religious commitment(Worthington, Wade, Hight, Ripley, McCullough, Berry, Schmitt, Berry, Bursley, and O'Connor, 2003). Based on the concept of consumer loyalty, religious commitment appears as a consequent construct of loyal behavior to religious organizations. Therefore, intrapersonal and interpersonal religious commitment constructs were included in the model to verify whether there was an effect of loyalty to religious organizations.(Mainardes, André, Júnior, and Sepulcri, 2019).

\section{Hypothesis Development}

Research by Ardyan et al. (2016) has proven that brand experience has significantly increased emotional attachment to brands. Khan and Rahman (2017) also emphasize that managers must provide a unique brand experience to customers to create emotional attachments between customers and brands. Customer interactions with brands are classified by certain levels of cognitive, emotional, and behavioral activity(Kumar, Rajan, Gupta, and Pozza, 2019). Customers become attached to the brand due to positive experiences, which plays a strong role in delivering satisfaction(Kang, Manthiou, Sumarjan, and Tang, 2017).Finally, because positive experiences lead to happiness, having a positive brand experience can develop a memory with a brand, which creates an attachment to the brand(Chaplin, Lowrey, Ruvio, Shrum, and Vohs, 2020). Positively experiencing a brand, consumers create memories and a sense of belonging to it, which can support the creation of emotional attachments(Reihani, Abdolvand, and Khounsiavash, 2019). Therefore, experience determines the strength of the relationship between consumers and brands.

This internal, positive response, resulting from a pleasant experience, will become a positive memory, resulting in creating a link with the brand(Ramirez and Merunka, 2019). This study hypothesizes that the same process applies to church contexts. Based on these arguments, this study proposes:

\section{H1: Brand experience affects the emotional attachment of the Mawar Sharon Church congre- gation in West Surabaya.}

The process by which a person develops trust in a brand depends on his brand experience (Khan and Fatma, 2019). Positive brand experiences tend to produce positive emotional and cognitive states, leading to psychological satisfaction with the brand (Sharma and Klein, 2020). This positive brand experience occurs when the value of a good 
interaction with a brand outweighs the negative value (Quan, Chi, Nhung, Ngan, and Phong, 2020). Iglesias, Markovic, Bagherzadeh, and Singh (2020) found a positive relationship between perceived brand value and trust. Evidence in the existing literature suggests that a positive brand experience results in future repurchases and a higher positive experience from these repeat purchases. More and more customers tend to trust these brands (Saragih, Surya, Rahayu, Harianto, Harahap, and Widodo, 2019).

Therefore, the higher the level of positive brand experience that customers realize, the more satisfied they are and tend to trust the brand. Experience with brands serves as an important source of personal input that can foster trust in consumers. Ha and Perks (2005, in Khan and Fatma, 2019) studied electronic consumer behavior found that brand trust is achieved through information search and various brand experiences. Lee and Jeong (2014, in Khan and Fatma, 2019) also found a significant positive effect of online brand experience on hotel brands' trust. Thus, based on the above arguments, this study proposes:

H2: Brand experience affects the brand trust of the Mawar Sharon Church congregation in West Surabaya.

The customer's return to the same brand depends largely on the experience with the brand, especially the intellectual experience, which leads the customer to increase loyalty (ability to pay more, positive verbal communication about the brand, repurchase intention, or retention of the same brand) (Ong, Lee, and Ramayah, 2018). Brand experience results from stimulation that triggers customer enthusiasm and delight; thus, customers will be encouraged to repeat the experience as often as possible(Ong et al., 2018). Other than that,Kang et al., (2017) stated that brand experience is a key factor that plays a role in achieving and sustaining business success and in building long-term bonds with consumers.

Previous research has shown a significant positive relationship between brand experience and brand loyalty(Ardyan et al., 2016; Ong et al., 2018). Moreover, in a church context,Booysen (2016)also succeeded in proving that brand experience impacts the satisfaction and brand loyalty of the church congregation. Based on the above arguments, this study proposes:
H3: Brand experience affects brand loyalty of the Mawar Sharon Church congregation in West Surabaya.

Customers tend to feel secure when consuming emotionally attached brands(Halloran, 2014). In this case, the customer will evaluate the brand to see if it matches their interests(Belaid and Behi, 2011). Brand engagement involves a personal history between the consumer and the brand, which can be strengthened by experience, consumers tend to develop a strong desire to continue the relationship with the brand and trust in its ability to keep its promises.(Belaid and Behi, 2011). Tsai (2014)states that when consumers have a strong emotional attachment to a brand, it stimulates positive emotions about safety and trust. Trust is not always a prerequisite of brand attachment but it plays a major role in enhancing this affective bond (Belaid and Behi, 2011). In addition, emotional attachments can strengthen brand trust. In fact, as in interpersonal relationships, passion and feelings of attachment lead to a high desire to depend and believe that the partner will fulfill a promise. Because it is attached to a brand, consumers can be sure that the brand does not intend to lie, break promises, or take advantage of consumer vulnerabilities. This study hypothesizes that the same process applies to church contexts. Based on these arguments,

H4: Emotional attachment affects the brand trust of the Mawar Sharon Church congregation in West Surabaya.

Khan and Rahman (2017) succeeded in showing the positive effects of consumer attachment to human brands on satisfaction, trust, and commitment. Thompson et al. (2005, in Khan and Rahman, 2017) found that emotional attachment is a good predictor of brand loyalty. According to Grisaffe and Nguyen (2011, in Khan and Rahman, 2017), emotional attachments offer special promises related to brands, and brand loyalty is the impact of deep emotional attachments. Thus, brand loyalty is a combination of emotional attachment and affective involvement (Atulkar and Kesari 2018). This study hypothesizes that the same process applies to church contexts. Based on the above arguments, this study proposes:

H5: Emotional attachment affects brand loyalty of the Mawar Sharon Church congregation in West Surabaya. 
According to Lien, Wen, Huang, and Wu (2015), trust is one of customer and company relationships' main features. It also refers to a customer's positive belief in a perceived product, service and brand(Park and Kim, 2016). Brand trust is conceptualized as consumers' willingness to rely on the brand and its promises, which are considered important antecedents of brand loyalty.(He, Li, and Harris., 2012). Brand trust has a positive influence on brand loyalty and motivates customers to demonstrate trust in the brand and maintain long-term relationships(Lin, Lobo, and Leckie, 2017). Thus, trusted brands are bought more frequently, as there is less perceived risk of choosing or buying a particular brand. This study hypothesizes that the same process applies to church contexts. Based on the above arguments, this study proposes:

H6: Brand trust affects brand loyalty of the Mawar Sharon Church congregation in West Surabaya.

The direct impact of brand attachment on brand trust, brand attachment mediates the relationship between brand experience and brand trust. Positive experiences develop positive feelings about the brand(Lee, Jeon, and Yoon, 2010, in Kang et al., 2017)and furthermore building trust in the brand because the brand doesn't disappoint customers. Positive experiences felt by consumers build brand attachment support, which is the basis for brand relationships (Bowden, 2009, in Kang et al., 2017). Brand attachment involves a personal history between consumers and brands that can be strengthened by experience, consumers tend to develop a strong desire to continue the relationship with the brand and trust in their ability to keep their promises (Belaid and Behi, 2011, in Kang et al., 2017).

Research by Schultz, Einwiller, Brockmann, and Weitzl (2019) also shows that trust is moderated by a person's value attachments to the organization. When the value attachment is low, there is a stronger impact of reputation on trust in the organization than when the value attachment is high. In this case, value attachment is an emotional attachment to an organization based on shared values, which can moderate the effect of reputation on trust (Schultz et al., 2019). This study hypothesizes that the same process applies to church contexts. Based on these arguments, this study proposes:

H7: Brand Experience Influences Brand Trust Through Emotional Attachments.
Emotion is one of the things that lead consumers to choose and become regular customers of certain products or services (Levy and Hino, 2016). Consumers tend to be emotionally attached to products, services, and brands, which can directly affect consumer behavioral responses(He, Zhu, Gouran, and Kolo, 2016). According toBrown and Alnawas (2016), consumer brand relationship is a strong predictor of brand loyalty. Hung and $\mathrm{Lu}$ (2018)revealed that positive brand attachment is a strong rationale for repurchase intentions, and makes it possible to build strong relationships between brands and consumers.

Other than that,Japutra, Ekinci, and Simkin (2019)emphasizing the symbolic security role given by emotional attachments that make customers loyal. A study conducted in luxury restaurants revealed that satisfied customers are more likely to develop emotional attachments to brands, contributing to behavioral loyalty(Ammari, Niekerk, Khelil, and Chtioui, 2016). This study hypothesizes that the same process applies to church contexts. Based on these arguments, this study proposes:

H8: Brand experience affects brand loyalty through the emotional attachment of the Mawar Sharon Church congregation in West Surabaya

Experience in using the product is very important to support image and trust in the product and ultimately maintain customer loyalty(Semadi and Ariyanti, 2018). Trustworthiness is an important component of brand trust. This means that trust in a product or brand is a key value in determining brand trust. Higher user trust will create better brand trust and increase brand loyalty to a higher level.Yu and Yuan (2019)found that intellectual and relational experiences influence brand trust. Brand Experience serves as a source of personal input that can foster a sense of trust in consumers. Brand experience is needed to increase trust and ultimately create brand loyalty. Brand trust is found to be a mediator of the influence of the relationship between brand personality and brand loyalty (Mabkhot, Shaari, and Salleh, 2017). However, this study has not discussed the effect of brand trust as a mediator of the effect of the relationship between brand experience and brand loyalty. This study hypothesizes that the same process applies to church contexts. Based on these arguments, this study proposes: 
H9: Brand experience affects brand loyalty through the brand trust of the Mawar Sharon Church congregation in West Surabaya

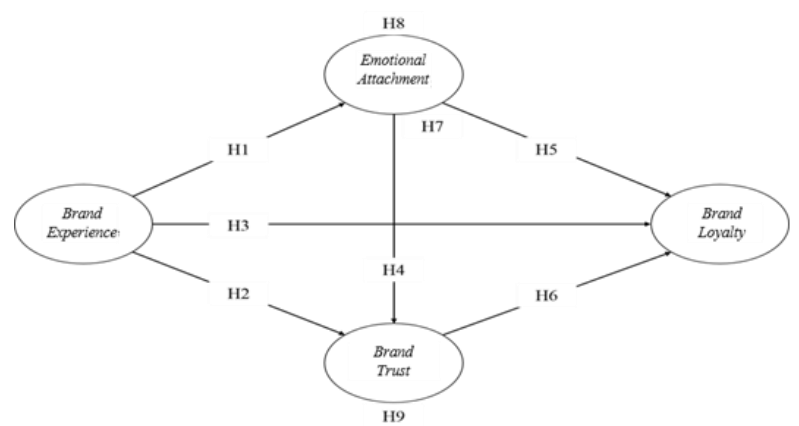

Figure 1 Structural Model

\section{RESEARCH METHODS}

This research is a type of quantitative research. Quantitative research according to Sekaran and Bougie (2017: 76) is a scientific method whose data is in the form of numbers or numbers that can be processed and analyzed using mathematical or statistical calculations. This research is classified as causal research. According to Sugiyono (2012: 59) a causal relationship is a relationship that is causal in nature. So, here there are the independent variables (influence) and the dependent variable (influenced).

\section{Research population and sample}

The population of this research is the Mawar Sharon Church congregation in West Surabaya. The sample selection method was carried out by purposive sampling, namely that purposive sampling was a technique of determining the sample with specific considerations (Sugiyono, 2012: 85). The number of respondents who joined the Mawar Sharon Church in West Surabaya and joined the Connect Group (CG) for at least 1 year was 160 people.

\section{Variable Research}

The independent variable in this study is brand experience. The intervening variables in this study are emotional attachment and brand trust. The dependent variable in this study is brand loyalty.

\section{Variable Measurement}

Measurement of the variables used in this study uses a Likert scale measurement technique which is proven to allow respondents to evaluate statements related to service quality and brand loyalty through customer satisfaction. According to Sugiyono (2012: 31), quantitative analysis uses a Likert scale to assess respondents' answers using positive statements

\section{Data analysis}

Data analysis breaks down the whole into smaller components to determine the dominant component, comparing one component to another, and comparing one or more components with the whole (Misbahudin and Hasan, 2013: 32). Data analysis techniques are used to answer problem formulations or test hypotheses that have been formulated (Sugiyono, 2015: 331). Data management in this study will use SEM-PLS with SmartPLS 3 software.

\section{RESULTS AND DISCUSSION}

Descriptive Statistics of Research Variables

Table 2: Descriptive Test Results

\begin{tabular}{|r|r|r|r|r|}
\hline No & Variable & $\begin{array}{r}\text { Mea } \\
\mathrm{n}\end{array}$ & $\begin{array}{r}\text { Standard } \\
\text { Deviatio } \\
\mathrm{n}\end{array}$ & $\begin{array}{r}\text { Class } \\
\text { Interval } \\
\mathrm{s}\end{array}$ \\
\hline 1 & $\begin{array}{r}\text { Brand } \\
\text { Experience }\end{array}$ & 4,676 & 0.554 & $\begin{array}{r}\text { Strongl } \\
\mathrm{y} \text { agree }\end{array}$ \\
\hline 2 & $\begin{array}{r}\text { Emotional } \\
\text { Attachmen } \\
\mathrm{t}\end{array}$ & 4,629 & 0.587 & $\begin{array}{l}\text { Strongl } \\
\mathrm{y} \text { agree }\end{array}$ \\
\hline 3 & $\begin{array}{r}\text { Brand } \\
\text { Trust }\end{array}$ & 4,404 & 0.697 & $\begin{array}{l}\text { Strongl } \\
\mathrm{y} \text { agree }\end{array}$ \\
\hline 4 & $\begin{array}{r}\text { Brand } \\
\text { Loyalty }\end{array}$ & 4.66 & 0.603 & $\begin{array}{l}\text { Strongl } \\
\mathrm{y} \text { agree }\end{array}$ \\
\hline
\end{tabular}

Brand experience operationally defined as the level of the experience felt by congregants in a church and measured by two dimensions: sensory and affective. Based on the results of Table 4.4 below, it is known that the results of the average calculation of the brand experience variable are 4,676 which is dominated by the fourth item with the statement "I feel the Mawar Sharon Church in West Surabaya evokes feelings" so it can be concluded that the respondents have a very high average answer. in answering the brand experience variable question.

Emotional attachment is operationally defined as the level of attachment between the congregation and the Mawar Sharon Church in West Surabaya so that the congregation feels part of the church. Based on the results of table 4.5 below, it is known that the results of the average calculation of the overall answers from respondents for the emotional attachment variable are 4,629 which is dominated by the fourth item with the statement "I feel at peace in the Mawar 
Sharon Church, West Surabaya" so it can be concluded that the respondents have The average answer is very high in answering the emotional attachment variable questions.

Brand trustoperationally defined as the level of congregation's trust towards other congregations who worship at Mawar Sharon Church, West Surabaya. Based on the results of table 4.6 below, it is known that the results of the average calculation of the overall answers of respondents for the brand trust variable are 4.404 which is dominated by the third item with the statement "my friends at Mawar Sharon Church, West Surabaya will do whatever they can to do. help others. " So it can be concluded that the respondents have a very high average answer in answering the question of the brand trust variable.

Brand loyalty is operationally defined as the level of a congregational commitment that is firmly held to always come and recommend Mawar Sharon Church, West Surabaya to others. Based on the results of table 4.7 below, it is known that the results of the average calculation of all respondents' answers to the brand loyalty variable are 4.66 which is dominated by the fourth item with the statement "I would recommend the Mawar Sharon Church, West Surabaya to others." So it can be concluded that the respondent has a very high average answer in answering the question of brand loyalty.

\section{Hypothesis testing}

If the value of the T-statistic> 1.96, the hypothesis can be accepted. The magnitude of the influence of the brand experience coefficient on emotional attachment is 0.698 and the t-statistic value is 11.014 , this number is greater than 1.96 . These results have a positive influence between brand experience on emotional attachments. In other words, the higher the brand experience, it can increase emotional attachment too. Based on the results that have been obtained, H1 is accepted.

The magnitude of the coefficient brand experience's influence to the brand trust of 0.019 and the $t$-statistic value of 0.168 , the amount is less than 1.96. These results indicate that there is no positive and significant influence between brand experience and brand trust. Based on the results obtained, $\mathrm{H} 2$ is rejected.

The magnitude of the coefficient brand experience's influence to brand loyalty of 0.275 and a t-statistic value of 3.111, the number is greater than 1.96. These results have a positive influence between brand experience and brand loyalty. In other words, the higher the brand experience, it can also increase brand loyalty. Based on the results that have been obtained, H3 is accepted. The magnitude of the influence of the coefficient emotional attachment to brand trust equal to 0.659 and the t-statistic value of 5,911 , the number is greater than 1.96. These results have a positive influence between emotional attachments to brand trust. In other words, the higher the emotional attachment, it can also increase brand trust. Based on the results that have been obtained, $\mathrm{H} 4$ is accepted.

The magnitude of the influence of the coefficient emotional attachment to brand loyalty of 0.433 and the $t$-statistic value of 4,292 , the number is greater than 1.96 . These results have a positive influence between emotional attachment to brand loyalty. In other words, the higher the emotional attachment, it can increase brand loyalty too. Based on the results that have been obtained, H5 is accepted.

The magnitude of the influence of the coefficient brand trust to brand loyalty of 0.157 and the $t$-statistic value is 2.379 , this number is greater than 1.96. These results have a positive influence between brand trust and brand loyalty. In other words, the higher the brand trust, it can also increase brand loyalty. Based on the results that have been obtained, H6 is accepted.

The magnitude of the influence of the coefficient brand experience to brand trust through emotional attachmentsequal to 0.698 and the $\mathrm{t}$ statistic value of 11,014 , the number is greater than 1.96. These results indicate a positive effect of emotional attachment as a mediator for brand experience on emotional attachments. Based on the results that have been obtained, H7 is accepted.

The magnitude of the coefficient brand experience's influence to brand loyalty through emotional attachmentsof 0.302 and the t-statistic value of 3,675 , the number is greater than 1.96 . These results indicate a positive effect of emotional attachment as a mediator of brand experience on brand loyalty. Based on the results that have been obtained, $\mathrm{H} 8$ is accepted.

The magnitude of the coefficient brand experience's influence on brand loyalty through brand trustof 0.003 and the $t$-statistic value of 0,157 
is less than 1.96. These results indicate that there is no positive and significant effect of brand trust as a mediator of brand experience on brand loyalty. Based on the results that have been obtained, H9 is rejected.

\section{Tabel 3. Result}

\begin{tabular}{|c|c|c|c|c|}
\hline $\begin{array}{l}\text { Hypothe- } \\
\text { sis }\end{array}$ & Influence & $\begin{array}{l}\text { Coeffi- } \\
\text { cient }\end{array}$ & $\begin{array}{c}T- \\
\text { Statistic } \\
\quad S\end{array}$ & Ket. \\
\hline H1 & $\begin{array}{l}\text { Brand Experience } \rightarrow \\
\text { Emotional Attach- } \\
\text { ment }\end{array}$ & 0.698 & 11,014 & Accept \\
\hline $\mathrm{H} 2$ & $\begin{array}{l}\text { Brand Experience } \rightarrow \\
\text { Brand Trust }\end{array}$ & 0.019 & 0.168 & Refuse \\
\hline H3 & $\begin{array}{l}\text { Brand Experience } \rightarrow \\
\text { Brand Loyalty }\end{array}$ & 0.275 & 3,111 & Accept \\
\hline $\mathrm{H} 4$ & $\begin{array}{l}\text { Emotional } \\
\text { Attachment } \rightarrow \\
\text { Brand Trust }\end{array}$ & 0.659 & 5,911 & Accept \\
\hline H5 & $\begin{array}{l}\text { Emotional } \\
\text { Attachment } \rightarrow \\
\text { Brand Loyalty }\end{array}$ & 0.433 & 4,292 & Accept \\
\hline H6 & $\begin{array}{l}\text { Brand Trust } \rightarrow \\
\text { Brand Loyalty }\end{array}$ & 0.157 & 2,379 & Accept \\
\hline $\mathrm{H} 7$ & $\begin{array}{l}\text { Brand Experience } \rightarrow \\
\text { Emotional Attach- } \\
\text { ment } \rightarrow \text { Brand } \\
\text { Trust }\end{array}$ & 0.460 & 4,148 & Accept \\
\hline H8 & $\begin{array}{l}\text { Brand Experience } \rightarrow \\
\text { Emotional Attach- } \\
\text { ment } \rightarrow \text { Brand Loy- } \\
\text { alty }\end{array}$ & 0.302 & 3,675 & Accept \\
\hline H9 & $\begin{array}{l}\text { Brand Experience } \rightarrow \\
\text { Brand Trust } \rightarrow \\
\text { Brand Loyalty }\end{array}$ & 0.003 & 0.157 & Refuse \\
\hline
\end{tabular}

\section{CONCLUSION}

This study examines brand experience and emotional attachment on brand trust and brand loyalty at Mawar Sharon Church, West Surabaya. Based on research that has been conducted using Structural Equation Modeling - Partial Least Square (SEM-PLS), several conclusions are generated as follows.

Brand experience $(\mathrm{BE})$ has a significant effect on emotional attachment (EA). This proves that brand experience can increase the effect of emotional attachment at the Mawar Sharon Church, West Surabaya.

Brand experience(BE) has no influence on brand trust (BT). This proves that brand experience is not necessarily able to increase brand trust in the Mawar Sharon Church, West Surabaya.

Brand experience (BE) has a significant effect on brand loyalty (BL). This proves that brand experience can increase brand loyalty, the effect of brand loyalty at the Mawar Sharon Church, West Surabaya.

Emotional attachment (EA) has a significant influence on brand trust (BT). This proves that emotional attachments can increase the influence of brand trust in the Mawar Sharon Church, West Surabaya. Emotional attachment (EA) has a significant effect on brand loyalty (BL). This proves that emotional attachments can increase the effect of brand loyalty at the Mawar Sharon Church, West Surabaya.

Brand trust (BT) has a significant effect on brand loyalty (BL). This proves that brand trust can increase the effect of brand loyalty in the Mawar Sharon Church, West Surabaya.

Brand experience(BE) has a significant effect on brand trust (BT) through emotional attachment (EA). This proves that brand experience can increase the influence of brand trust through emotional attachments to the Mawar Sharon Church, West Surabaya. Brand experience $(\mathrm{BE})$ has a significant effect on brand loyalty (BL) through emotional attachment (EA). This proves that brand experience can increase the effect of brand loyalty through emotional attachments to the Mawar Sharon Church, West Surabaya. Brand experience $(\mathrm{BE})$ has no influence on brand loyalty (BL) through brand trust (BT). This proves that brand experience through brand trust does not necessarily increase brand loyalty at the Mawar Sharon Church, West Surabaya.

This study's results can be used to reference research that has similar variables, namely brand experience, emotional attachment, brand trust, and brand loyalty. Future research is expected to be able to conduct research on other non-profit organizations or other services. (such as airlines, hotels, telecommunications, etc.). It is also expected to increase the number of respondents and expand the location of distribution to reach more respondents. Finally, it is expected that the variable influence of brand experience on brand trust and the influence of brand experience on brand loyalty through brand trust has insignificant results, for further research it is expected to improve this limitation and be able to explain the relationship between variables well.

It can be seen that the lowest respondent's assessment of the brand experience variable lies in the statement "I am often emotionally involved with the Mawar Sharon Church, West Surabaya." With this, the Mawar Sharon Church in West Surabaya needs to carry out activities that can build and engage the emotions of the congregation. For this reason, brand experience needs to be improved so that it will increase the positive experience of the congregation at Mawar Sharon Church, West Surabaya 
It can be seen that the lowest respondent's assessment of the emotional attachment variable lies in the statement, "I feel attached to the Mawar Sharon Church, West Surabaya." With this Mawar Sharon Church in West Surabaya needs to make a program so that there is a personal bond between the congregation and the Mawar Sharon Church in West Surabaya and the congregation has a more sense of belonging to the church. For this reason, emotional attachments need to be increased so that it will increase the positive emotional bond of the congregation at Mawar Sharon Church, West Surabaya.

It can be seen that the lowest respondent's assessment of the brand trust variable lies in the statement, "I feel that most of my friends at the Mawar Sharon Church, West Surabaya can be trusted". With this Mawar Sharon Church, West Surabaya, it is necessary to make a personal approach to the congregation or volunteers. Another activity that can be done is the personal bonding between congregations so that relational trust is created. For this reason, the Mawar Sharon Church in West Surabaya needs to increase brand trust so that it will increase the congregation's trust in the Mawar Sharon Church in West Surabaya.

It can be seen that the lowest respondent's assessment of the brand loyalty variable lies in the statement "I will be loyal to the church at Mawar Sharon Church, West Surabaya." With this the Mawar Sharon Church in West Surabaya needs to provide trust and confidence in order to increase the loyalty of the congregation to the Mawar Sharon Church in West Surabaya. For this reason, the Mawar Sharon Church in West Surabaya needs to increase brand loyalty so that it will create a good impression in the minds of the congregation towards the Mawar Sharon Church in West Surabaya.

\section{REFERENCES}

Andreini, D., Pedeliento, G., Zarantonello, L., dan Solerio, C. (2018). A renaissance of brand experience: Advancing the concept through a multi-perspective analysis. Journal of Business Research, 91, 123-133.

Ardyan, E., Kurnianingsih, H., Rahmawan, G., Wibisono, U., dan Winata, W. (2016). Enhancing brand experience along with emotional attachment towards trust and brand loyalty. Jurnal Manajemen dan Kewirausahaan, 18(1), 33-44.
Atulkar, S. dan Kesari, B. (2018), "A review on art of creating values in retail for improving business performance", Journal of Business Administration Research, 7(1), 22-26.

Ammari, B. N., Niekerk, V. M., Khelil, B. H. dan Chtioui, J. (2016), "The effects of brand attachment on behavioral loyalty in the luxury restaurant sector", International Journal of Contemporary Hospitality Management, 28(3), 559-585.

Barna Group. (2014). Five Trends Among the Unchurched. Didapatkan dari https://www.barna.com/research/fivetrends-among-t.

Belaid, S. dan Behi, T. A. (2011). The role of attachment in building consumer-brand relationships: an empirical investigation in the utilitarian consumption context, Journal of Product dan Brand Management, 20(1), 37-47.

Belk, R. W. (1988). Possessions and the Extended Self. Journal of Consumer Research. 15(2), 139168.

Bilangan Research Center. (2018). Dinamika Spiritualitas Generasi Muda Indonesia. Jakarta Utara: Yayasan Bilangan Research Center.

Booysen, E. (2016). Exploring the impact of brand experience on satisfaction and loyalty in churches and religious organisations in Johannesburg (Disertasi, University of Pretoria). Didapat dari

https://repository.up.ac.za/bitstream/hand le/2263/52347/Booysen_Exploring_2015.pdf ?sequence $=1$.

Brakus, J. J., Schmitt, B. H., dan Zarantonello, L. (2009). Brand experience: what is it? How is it measured? Does it affect loyalty?. Journal of marketing, 73(3), 52-68.

Chaplin, L. N., Lowrey, T. M., Ruvio, A. A., Shrum, L. J., dan Vohs, K. D. (2020). Age differences in children's happiness from material goods and experiences: The role of memory and theory of mind. International Journal of Research in Marketing, 37(3), 572-586.

Chaudhuri, A., dan Holbrook, M. B. (2001). The chain of effects from brand trust and brand affect to brand performance: the role of brand loyalty. Journal of marketing, 65(2), 81-93.

Coelho, F. J., Bairrada, C. M., dan de Matos Coelho, A. F. (2020). Functional brand qualities and perceived value: The mediating role of brand experience and brand personality. Psychology dan Marketing, 37(1), 
41-55.

Cohen, A. (2013). Organizational commitment theory. Encyclopedia of Management Theory. Thousand Oaks, California: SAGE.

Dalziel, N., Harris, F. dan Laing, A. (2011), "A multidimensional typology of customer relationships: from faltering to affective", International Journal of Bank Marketing, 29(5), 398-432.

Dowell, D., Heffernan, T. dan Morrison, M. (2013), "Trust formation at the growth stage of a business-to-business relationship: A qualitative investigation", Qualitative Market Research, 16(4), 436-451.

Dunaetz, D., Cullum, M., dan Barron, E. (2018). Church size, pastoral humility, and member characteristics as predictors of church commitment. Theology of Leadership Journal, 1, 125-138.

Eisingerich, A. B., dan Rubera, G. (2010). Drivers of brand commitment: A cross-national investigation. Journal of International Marketing, 18(2), 64-79.

Eskafi, M., Hosseini, S.H., dan Yazd, A.M. (2013). The value of telecom subscribers and customer relationship management. Business Process Management Journal, 19, 737-748.

Granger, K., Lu, V. N., Conduit, J., Veale, R., dan Habel, C. (2014). Keeping the faith! Drivers of participation in spiritually-based communities. Journal of Business Research, $67(2), 68-75$.

Halloran, T. (2014). Romancing the brand: How brands create strong, intimate relationships with consumers. Hoboken, NJ: John Wiley dan Sons.

He, H., Li, Y., dan Harris, L. (2012). Social identity perspective on brand loyalty. Journal of business research, 65(5), 648-657.

He, H., Zhu, W., Gouran, D., dan Kolo, O. (2016). Moral identity centrality and cause-related marketing: The moderating effects of brand social responsibility image and emotional brand attachment. European Journal of Marketing, 50(1/2), 236-259.

Brown, H. J. dan Alnawas, I. (2016). Service quality and brand loyalty: The mediation effect of brand passion, brand affection and self-brand connection. International Journal of Contemporary Hospitality Management, 28(12), 2771-2794.
Hicks, R. (2012). Hillsong-Australia's Most Powerful Brand'. Mumbrella, Sydney, Viewed, 26(07), 2012.

Hirschman, A. O. (1970). Exit, Voice and Loyalty: Responses to Decline in Firms. Cambridge, Massachusetts: Harvard University Press.

Hobbs, J. E., dan Goddard, E. (2015). Consumers and trust. Food Policy, 52, 71-74.

Huang, C. C. (2017). The impacts of brand experiences on brand loyalty: mediators of brand love and trust. Management Decision, 55(5), 915-934.

Hung, H. Y., dan Lu, H. T. (2018). The rosy side and the blue side of emotional brand attachment. Journal of Consumer Behaviour, 17(3), 302-312.

Husein, U. (2009). Riset Pemasaran dan Perilaku Konsumen. Jakarta: PT. Gramedia.

Iglesias, O., Markovic, S., Bagherzadeh, M., dan Singh, J. J. (2020). Co-creation: A key link between corporate social responsibility, customer trust, and customer loyalty. Journal of Business Ethics, 163(1), 151-166.

Japutra, A., Ekinci, Y., dan Simkin, L. (2019). Selfcongruence, brand attachment and compulsive buying. Journal of Business Research, 99, 456-463.

Jiménez, F. R., dan Voss, K. E. (2014). An alternative approach to the measurement of emotional attachment. Psychology and Marketing, 31(5), 360-370.

Kang, J., Manthiou, A., Sumarjan, N., dan Tang, L. (2017). An Investigation of Brand Experience on Brand Attachment, Knowledge, and Trust in the Lodging Industry. Journal of Hospitality Marketing and Management, 26(1), 1-22.

Khan, A., Mohammad, A. S., dan Muhammad, S. (2020). An integrated model of brand experience and brand love for halal brands: survey of halal fast food consumers in Malaysia. Journal of Islamic Marketing.

Khan, I., dan Fatma, M. (2019). Connecting the dots between CSR and brand loyalty: the mediating role of brand experience and brand trust. International Journal of Business Excellence, 17(4), 439-455.

Khan, I., dan Rahman, Z. (2017). Brand experience and emotional attachment in services: The moderating role of gender. Service Science, 9(1), 50-61.

Kumar, V., Rajan, B., Gupta, S., dan Pozza, D. I. 
(2019). Customer engagement in service. Journal of the Academy of Marketing Science, 47(1), 138-160.

Lee, B. S., Park, K. H., dan Cho, J. H. (2011). A Study on the Effect of Selection Attributes on Consumer Satisfaction and Repurchase intention about HMR - In case of Ready-toend-cook -. Culinary Science and Hospitality Research, 17(2), 85-97.

Levy, S., dan Hino, H. (2016). Emotional brand attachment: a factor in customer-bank relationships. International Journal of Bank Marketing, 34(2), 136-150.

Lien, C. H., Wen, M. J., Huang, L. C., dan Wu, K. L. (2015). Online hotel booking: The effects of brand image, price, trust and value on purchase intentions. Asia Pacific Management Review, 20(4), 210-218.

Lin, J., Lobo, A., dan Leckie, C. (2017). The role of benefits and transparency in shaping consumers' green perceived value, self-brand connection and brand loyalty. Journal of Retailing and Consumer Services, 35, 133-141.

Mabkhot, H. A., Shaari, H., dan Salleh, S. M. (2017). The influence of brand image and brand personality on brand loyalty, mediating by brand trust: An empirical study. Jurnal Pengurusan (UKM Journal of Management), 50.

Mainardes, E. W., André, O. D. F., Júnior, S. A. P., dan Sepulcri, L. M. C. B. (2019). Antecedents and Consequents of Loyalty to a Religious Organization. Journal of Nonprofit dan Public Sector Marketing, 1(24).

Misbahudin dan Hasan, I. (2013). Analisis Data Penelitian Dengan Statistik. Jakarta: Bumi Aksara.

Morrison, S., dan Crane, F. G. (2007). Building the service brand by creating and managing an emotional brand experience. Journal of brand management, 14(5), 410-421.

Mullen, T. (2020). Young people and the Baptist church: Staying and leaving. (Tesis, Edith Cowan University School of Arts and Humanities, Joondalup, Australia). Didapat dari https://ro.ecu.edu.au/theses/2304/.

Naggar, R. A. A., dan Bendary, N. (2017). The Impact of Experience and Brand trust on Brand loyalty, while considering the mediating effect of brand Equity dimensions, an empirical study on mobile operator subscribers in Egypt. The Business dan Management Review, 9(2), 16-25.
Oliver, R. L. (1999). Whence Consumer Loyalty? Journal of Marketing, 63, 33-44.

Ong, C. H., Lee, H. W., dan Ramayah, T. (2018). Impact of brand experience on loyalty. Journal of Hospitality Marketing and Management, 27(7), 755-774.

Park, H., dan Kim, Y. K. (2016). Proactive versus reactive apparel brands in sustainability: Influences on brand loyalty. Journal of Retailing and Consumer Services, 29, 114-122.

Park, W. C., dan MacInnis, D. J. (2006). What's in and what's out: Questions on the boundaries of the attitude construct. Journal of Consumer Research, 33(1), 16-18.

Park, W. C., MacInnis, D. J., Priester, J., Eisingerich, A. B., dan Lacobucci, D. (2010). Brand attachment and brand attitude strength: Conceptual and empirical differentiation of two critical brand equity drivers. Journal of Marketing, 74(6), 1-17.

Quan, N., Chi, N., Nhung, D., Ngan, N., dan Phong, L. (2020). The influence of website brand equity, e-brand experience on eloyalty: The mediating role of e-satisfaction. Management Science Letters, 10(1), 63-76.

Rainer, T. S. (2013). The Main Reason People Leave a Church. Didapat dari https://churchanswers.com/blog/the-mainreason-people-leave-a-church/ 25 Agustus 2020, pukul 23.46 WIB.

Ramirez, H. R. dan Merunka, D. (2019), "Brand experience effects on brand attachment: the role of brand trust, age, and income", European Business Review, 31(5), 610-645.

Reichheld, F. F., dan Teal, T. (1996). The Loyalty Effect: The Hidden Force Behind Growth, Profits, and Lasting Value. Harvard Business School Press. Boston, MA.

Reihani, N., Abdolvand, M.A., dan Khounsiavash, M. (2019). Brand attachment in consumerbrand relationship. Journal of System Management, 5(2), 41-60.

Riches, T., dan Wagner, T. (2017). The Hillsong Movement Examined: You Call Me Out Upon the Waters. Springer.

Saragih, M. G., Surya, E. D., Rahayu, S., Harianto, H., Harahap, R., dan Widodo, S. (2019). Analysis Of Brand Experience And Brand Satisfaction With Brand Loyalty Through Brand Trust As A Variable Mediation. Journal of International Conference Proceedings, 2(3), 139-148. 
Schoeman, W. K. (2014). Agter die syfers is gelowiges, gemeentes en die kerk,'n prakties teologiese refleksie oor lidmaatskap. HTS: Theological Studies, 70(1), 1-10.

Schultz, C., Einwiller, S., Brockmann, J., dan Weitzl, W. (2019). When Reputation Influences Trust in Nonprofit Organizations. The Role of Value Attachment as Moderator. Corporate Reputation Review, 22(4), 159-170.

Sekaran, U., dan Bougie, R. (2017). Metode Penelitian Untuk Bisnis - Pendekatan Pengembangan - Keahlian. Edisi 6. Buku 1. Jakarta : Salemba Empat.

Semadi, I. P., dan Ariyanti, M. (2018). The influence of brand experience, brand image, and brand trust on brand loyalty of $\mathrm{ABC}$ Cash. Asian Journal of Management Sciences dan Education Vol. 7 (3), 7(3), 12-23.

Sharma, V. M., dan Klein, A. (2020). Consumer perceived value, involvement, trust, susceptibility to interpersonal influence, and intention to participate in online group buying. Journal of Retailing and Consumer Services, 52, 101946.

Silalahi, U. (2012). Metode Penelitian Sosial. Bandung: Refika Aditama.

Sugiyono. (2008). Metode Penelitian Pendidikan Pendekatan Kuantitatif dan RED. Bandung: Alfabeta.

Sugiyono. (2012). Metode Penelitian Kuantitatif Kualitatif dan RED. Bandung Alfabeta.

Sugiyono (2015). Metode Penelitian Kombinasi (Mix Methods). Bandung: Alfabeta.

Sunarno, Y. A., dan Kristanto, L. (2016). Gereja Mawar Sharon Pusat di Surabaya. JURNAL EDIMENSI ARSITEKTUR, IV(2), 345-352.

Thompson, M., MacInnis, D., dan Park, W. (2005). The ties that bind: measuring the strength of customers attachment to brands. Journal of Consumer Psychology, 15(1), 77-91.

Thumma, S., dan Travis, D. (2007). Beyond megachurch myths: What we can learn from America's largest churches (Vol. 21). Hoboken, NJ: John Wiley dan Sons.

Tsai, S. P. (2014). Meaning threats heighten consumer attachment: Implications for global brand management. European Management Journal, 32(6), 991-1000.

Wellman, J. K., dan Corcoran, K. E. (2013). Religion and regional culture: Embedding religious commitment within place. Sociology of Religion: A Quarterly Review, 74(4), 496-520.

Worthington, E. L., Wade, N. G., Hight, T. L., Ripley, J. S., McCullough, M. E., Berry, J. W., Schmitt, M. M., Berry, J. T., Bursley, K. H., dan O'Connor, L. (2003). The Religious Commitment Inventory-10: Development, refinement, and validation of a brief scale for research and counseling. Journal of Counseling Psychology, 50(1), 84.

Xie, Y., dan Peng, S. (2011). How do corporate associations influence customer relationship strength? the effects of different types of trust. Journal of Strategic Marketing, 19(5), 443-454.

Yip, J., dan Ainsworth, S. (2013). "We aim to provide excellent service to everyone who comes to church!": Marketing megachurches in Singapore. Social Compass, 60(4), 503-516.

Yu, X., dan Yuan, C. (2019). How consumers' brand experience in social media can improve brand perception and customer equity. Asia Pacific Journal of Marketing and Logistics, 31(5), 1233-1251.

Zeithaml, V. A., Berry, L. L., dan Parasuraman, A. (1996). The behavioral consequences of service quality, 60(2), 31-4 